\title{
Microsphere-Based Immunoassay for the Detection of Azaspiracids
}

\author{
Laura P. Rodríguez ${ }^{1}$, Natalia Vilariño $0^{1,{ }^{*},}$ M. Carmen Louzao ${ }^{1}$, Tobin J. Dickerson ${ }^{2}$, K. C. \\ Nicolaou $^{3,4,5}$, Michael O. Frederick ${ }^{3,4}$, and Luis M. Botana ${ }^{1, *}$ \\ ${ }^{1}$ Universidad de Santiago de Compostela, Departamento de Farmacología, Facultad de \\ Veterinaria, 27002 Lugo, Spain \\ ${ }^{2}$ Department of Chemistry and Worm Institute of Research and Medicine, The Scripps Research \\ Institute, 10550 North Torrey Pines Road, La Jolla, CA 92037 (USA) \\ ${ }^{3}$ Department of Chemistry and The Skaggs Institute of Chemical Biology, The Scripps Research \\ Institute, 10550 North Torrey Pines Road, La Jolla, CA 92037 (USA) \\ ${ }^{4}$ Department of Chemistry and Biochemistry, University of California, San Diego, 9500 Gilman \\ Drive, La Jolla, CA 92093 (USA) \\ ${ }^{5}$ Department of Chemistry, BioScience Research Collaborative, Rice University, 6500 Main \\ Street, Houston, TX 77030 (USA)
}

\section{Abstract}

Azaspiracids (AZAs) are a group of lipophilic toxins discovered in mussels from Ireland in 1995 following a human poisoning incident. Nowadays the regulatory limit for AZAs in many countries is set at $160 \mathrm{Fg}$ of azaspiracid equivalents per $\mathrm{kg}$ of shellfish meat. In this work a microspherebased immunoassay has been developed for the detection of AZAs using a Luminex system. This method is based on the competition between AZA-2 immobilized onto the surface of microspheres and free AZAs for the interaction with a monoclonal anti-azaspiracid antibody (mAb 8F4). In this inhibition immunoassay the amount of mAb $8 \mathrm{~F} 4$ bound to AZA-2-microspheres was quantified using a phycoerythrin-labeled anti-mouse antibody, and the fluorescence was measured with a Luminex analyzer. Simple acetate/methanol or methanol extractions yielded final extracts with no matrix interferences and adequate recovery rates of $86.5 \%$ and $75.8 \%$, respectively. In summary, this work presents, a sensitive and easily performed screening method capable of detecting AZAs at concentrations below the range of the European regulatory limit using a microsphere/flow cytometry system.

\section{Keywords}

Azaspiracid poisoning; anti-azaspiracid antibody; flow fluorimetry system

(c) 2013 Elsevier Inc. All rights reserved.

*To whom correspondence should be addressed: Luis M. Botana, Natalia Vilariño, Departamento de Farmacología, Facultad de Veterinaria, Campus Universitario, 27002 Lugo, Spain, luis.botana@usc.es, natalia.vilarino@usc.es, Telephone and Fax: +34 982822233.

Publisher's Disclaimer: This is a PDF file of an unedited manuscript that has been accepted for publication. As a service to our customers we are providing this early version of the manuscript. The manuscript will undergo copyediting, typesetting, and review of the resulting proof before it is published in its final citable form. Please note that during the production process errors may be discovered which could affect the content, and all legal disclaimers that apply to the journal pertain. 


\section{Introduction}

Azaspiracids (AZAs) are a class of polyether toxins discovered in 1995 due to a human intoxication episode reported in The Netherlands after the consumption of contaminated mussels (Mytilus edulis) harvested from Killary Harbour, Ireland [1,2]. These toxins are produced by the photosynthetic thecate dinoflagellate Azadinium spinosum [3].

The main toxin found in contaminated samples, azaspiracid-1 (AZA-1) was isolated in 1998 [2], and its structure was later fully elucidated through synthetic studies [4-10]. To date, more than 30 analogues have been described [11], and AZA toxins have been reported from many locations around the world [2,12-17].

The symptoms observed during azaspiracid poisoning (AZP) in humans are similar to signs of diarrhetic shellfish poisoning (DSP), including nausea, vomiting, severe diarrhea and stomach cramps [1]. These toxins have been responsible for several incidents of shellfish poisoning in Europe [18], and, as a consequence, a maximum level of $160 \mathrm{Fg}$ of AZA equivalents per $\mathrm{kg}$ of shellfish meat destined for human consumption has been established in many countries for AZA-1, azaspiracid-2 (AZA-2) and azaspiracid-3 (AZA-3) [19] (Fig. 1), the better-known compounds of the group.

Azaspiracids have been described to induce multiple system damage in rodents and cause, occasionally, the appearance of lung tumors [20]. Several in vitro studies have demonstrated the high cytotoxicity of AZA-1, affecting different cell lines [21]; however, the mechanism of action of these toxins remains to be determined. Mouse and rat bioassays have been used for the detection of AZAs [1]. Nevertheless, mammalian bioassays have several disadvantages due to their lack of sensitivity and specificity and ethical considerations. Analytical methods using mass spectrometry (MS) have been developed for the detection of marine toxins, in order to reduce the number of laboratory animals sacrificed every year for this purpose. Recently, LC-MS/MS has been established as the official reference method to detect AZAs in Europe [22]. MS-based methods have some drawbacks due to the use of large amounts of solvents as well as requiring highly qualified personnel and expensive instrumentation. Moreover, these methods need certified standards of all analogues of a toxin group for accurate estimation of toxicity [23], and the presence of new possibly toxic compounds would be missed with these techniques. The development of alternative assays suitable for screening high numbers of samples for marine biotoxins is needed to reduce the number of analyses by more expensive and time consuming methods.

In the last few years, multiplexed assays that enable the rapid analyses of a large number of samples by combining the use of microspheres with flow fluorimetry have been described for the analysis of several contaminants in food $[24,25]$. The Luminex system is based on laboratory multi-analyte profiling $\left(\operatorname{LabMAP}^{\mathrm{TM}}\right)$ technology that combines the use of fluorescently dyed 5.6 micron polystyrene microspheres with a Luminex analyzer. One hundred classes of microspheres are differentiated by their internal fluorescence. The surface carboxyl groups of each microsphere are used for coating with an analyte specific detection molecule, and a reporter molecule labeled with phycoerythrin (PE) enables quantification of analyte-related signal. Therefore, Luminex technology allows the simultaneous detection of multiple analytes within a single sample by combining different analyte-specific microsphere classes.

The aim of this work was to develop a flow fluorimetry-based immunoassay for AZAs detection using a specific monoclonal antibody, known as mAb 8F4, and a Luminex system. 


\section{Materials and methods}

\section{Materials}

Certified reference standard materials of azaspiracid-1 (AZA-1), 8-methylazaspiracid (AZA-2) and 22-demethylazaspiracid (AZA-3) were obtained from the Institute for Marine Biosciences, National Research Council (Halifax, Canada). AZA-2, used for immobilization on the microsphere surface, was synthesized by Nicolaou and co-workers as previously described $[5,7,9,26,27]$. $N$-hydroxysuccinimide (NHS), boric acid, bovine serum albumin (BSA), Tween-20, dimethyl sulfoxide (DMSO) and sodium tetraborate decahydrate were obtained from Sigma-Aldrich (Madrid, Spain), and 1-ethyl-3-(3-dimethylaminopropyl) carbodiimide hydrochloride (EDC) was purchased from Pierce (Rockford, Illinois). Ethylenediamine and sodium azide were obtained from Fluka (Steinheim, Germany). Phycoerythin (PE) Goat Anti-Mouse IgG was purchased from Invitrogen (Eugene, Oregon), and the anti-azaspiracid monoclonal antibody $(\mathrm{mAb}) 8 \mathrm{~F} 4$ was produced as previously described [28]. Sodium chloride, acetic acid, methanol, sodium acetate anhydrous and sodium phosphates were obtained from Panreac (Barcelona, Spain). Ethanolamine was supplied by BiaCore AB (Uppsala, Sweden). Mussels (Mytilus galloprovincialis), scallops (Pecten maximus), clams (Ruditapes philippinarum) and cockles (Cerastoderma edule) were purchased from the market (Lugo, Spain). Calibration and performance verification kits for Luminex 200, carboxylated microspheres (LC10077-01) and sheath fluid were purchased from Luminex Corporation (Austin, Texas). Multiscreen 96-well filter plates (Durapore membrane), $33 \mathrm{~mm}$ Milex filter with $0.22 \mu \mathrm{m}$ pore size and $0.45 \mu \mathrm{m}$ pore size Ultrafree-MC centrifugal filters (Durapore membrane) were purchased from Millipore (Madrid, Spain).

Phosphate-buffered saline solution (PBS) was $130 \mathrm{mM} \mathrm{NaCl}, 1.5 \mathrm{mM} \mathrm{NaH}_{2} \mathrm{PO}_{4}$, and 8.5 $\mathrm{mM} \mathrm{Na}_{2} \mathrm{HPO}_{4}$, pH 7.4. PBS-BT solution was PBS supplemented with $0.1 \%$ w/v BSA and $0.1 \% \mathrm{v} / \mathrm{v}$ Tween-20. Buffer solutions were filtered through a $0.22 \mu \mathrm{m}$ pore size filter before use.

\section{Coupling of azaspiracid to carboxylated microspheres}

AZA-2 was immobilized on the surface of carboxylated microspheres using EDC/NHS. The coupling protocol was performed in an opaque $1.2 \mu \mathrm{m}$ filter microplate where $150 \mu \mathrm{L}$ of a mixture of equal volumes of EDC and NHS, at concentrations of $75 \mathrm{mg} / \mathrm{mL}$ and $11.5 \mathrm{mg}$ / $\mathrm{mL}$, respectively (both reagents dissolved in water), were added to a well-microplate containing $1.2 \times 10^{6}$ prewashed microspheres (LC10077-01). After 30 min of incubation the EDC/NHS mixture was removed by filtration and then $150 \mu \mathrm{L}$ of $1 \mathrm{M}$ ethylenediamine (dissolved in $50 \mathrm{mM}$ borate buffer solution, $\mathrm{pH} 8.5$ ) were added to the well and let to react for $1 \mathrm{~h}$. Then ethylenediamine was removed and $150 \mu \mathrm{L}$ of $1 \mathrm{M}$ ethanolamine were added. The ethanolamine was filtered off after 20 min. Finally, $50 \mu \mathrm{g}$ of AZA-2 dissolved in $10 \mu \mathrm{L}$ of DMSO, $30 \mu \mathrm{L}$ of acetate buffer solution $\mathrm{pH} 4.5$ and $10 \mu \mathrm{L}$ of a mixture of equal volumes of EDC $(54 \mathrm{mg} / \mathrm{mL})$ and NHS $(24 \mathrm{mg} / \mathrm{mL})$ were added to the preactivated microspheres and allowed to couple for $4 \mathrm{~h}$. Once the coupling reaction period was completed, the microspheres were washed three times with $200 \mu \mathrm{L}$ of PBS-BT and stored in PBS-BT supplemented with $0.01 \% \mathrm{w} / \mathrm{v}$ sodium azide at $4{ }^{\circ} \mathrm{C}$ in the dark until use. All the incubations were performed with constant shaking $(700 \mathrm{rpm})$ at room temperature in the dark. All washes consisted of the addition of $200 \mu \mathrm{L}$ PBS-BT, and solutions were removed using a vacuum manifold without exceeding $5 \mathrm{~mm} \mathrm{Hg}$ of pressure.

\section{Microsphere-based immunoassay for the detection of AZAs}

An inhibition immunoassay for the detection of AZAs was designed using the competition between AZA-2 immobilized on the microsphere surface and free AZAs for the interaction with a monoclonal anti-AZA antibody (mAb 8F4). The first step was the incubation of 60 
$\mu \mathrm{L}$ of sample or calibration solution with $60 \mu \mathrm{L}$ of a 1:50000 dilution of the mAb 8F4 (2.8 $\mathrm{mg} / \mathrm{mL}$, stock solution) in $1.5 \mathrm{~mL}$ microtubes for $30 \mathrm{~min}$. Then $100 \mu \mathrm{L}$ of this mixture were added to a well of an opaque, $1.2 \mu \mathrm{m}$ filter plate containing $2 \times 10^{3}$ prewashed AZA-2coupled-microspheres. The AZA-2-microspheres were incubated with the sample-mAb 8F4 mixture overnight $(15 \mathrm{~h})$ at $4{ }^{\circ} \mathrm{C}$ with constant shaking. After three washing steps with PBSBT, $100 \mu \mathrm{L}$ of a 1:2000 dilution of PE-labeled anti-mouse antibody $(1 \mathrm{mg} / \mathrm{mL}$, stock solution) were added to the microspheres for $30 \mathrm{~min}$, followed by three additional washes. Finally, the microspheres were resuspended in $100 \mu \mathrm{L}$ of PBS-BT.

\section{Quantification of the binding signal}

PE fluorescence intensity bound to the AZA-2-microspheres was measured with a Luminex 200 analyzer (LuminexCorp, Austin, Texas). The Luminex analyzer detects individual beads by a flow fluorimetry system using a $635 \mathrm{~nm}$ laser to classify microspheres. PE (analyterelated) fluorescence is quantified after excitation with a $532 \mathrm{~nm}$ green laser. Default values of 7500-13500 were used for doublet discriminator gating of microspheres. The acquisition volume was $75 \mu \mathrm{L}$ and minimum bead count was 100 .

The mAb 8F4 binding response for each condition was expressed as percent of maximum binding and calculated as follows: $\% \mathrm{R}=\left\{\left(\mathrm{S}_{\mathrm{i}}-\mathrm{S}_{\min }\right) /\left(\mathrm{S}_{\max }-\mathrm{S}_{\min }\right)\right\} \times 100$, where \% R is the percentage of $\mathrm{mAb} 8 \mathrm{~F} 4$ binding response, $\mathrm{S}_{\mathrm{i}}$ is the signal obtained for a given condition, $\mathrm{S}_{\max }$ is the signal obtained in control wells containing AZA-2-microspheres and $\mathrm{mAb} 8 \mathrm{~F} 4$, and $\mathrm{S}_{\min }$ is the signal obtained in control wells containing AZA-2-microspheres and no mAb $8 \mathrm{~F} 4$.

\section{Shellfish extraction procedure}

Shellfish meat (whole body of mussel, cockle or clam, and muscle plus gonad of scallop) was homogenized with a blender, divided into aliquots and stored at $-20^{\circ} \mathrm{C}$ until use. The extraction procedure consisted of the addition of $5 \mathrm{~mL}$ of the extraction solution (70\% methanol in $0.2 \mathrm{M}$ sodium acetate buffer, $\mathrm{pH} 5.0, \mathrm{MeOH} / \mathrm{NaOAc}$ ) to $1 \mathrm{~g}$ of sample homogenate. The mixture was vortexed for $3 \mathrm{~min}$ and then centrifuged at $3600 \mathrm{~g}$ during 8 min at room temperature. The supernatant was saved and the pellet was re-extracted with 3 $\mathrm{mL}$ of the extraction solution, as described. The supernatants were combined and the volume was made up to $10 \mathrm{~mL}$ with $\mathrm{MeOH} / \mathrm{NaOAc}$. This extract was then diluted $1: 10(\mathrm{v} / \mathrm{v})$ in PBSBT and filtered through a $0.45 \mathrm{Fm}$ filter. Mussels, scallops, clams and cockles used in this work did not contain detectable amounts of AZAs when tested by LC-MS/MS [29].

\section{Safety}

Azaspiracids are toxins with high, acute intraperitoneal toxicity in mice. Although no human intoxication has been reported, standard solutions should be handled with gloves and eye protection should be worn at all times. Appropriate disposal methods should also be utilized.

\section{Data analysis}

The results are expressed as mean \pm SEM (standard error of the mean). For every experiment all conditions were tested in duplicate. The calibration curves were fitted using a four-parameter logistic equation obtained by a nonlinear regression fitting procedure (GraphPad Prism 5.0). The four-parameter fit equation was: $y=\{\operatorname{Min}+(\operatorname{Max}-\operatorname{Min}) / 1+10$ $\left.\exp \left(\left(\operatorname{logEC} \mathrm{C}_{50}-\mathrm{x}\right) \mathrm{n}_{\mathrm{H}}\right)\right\}$, where Min is the bottom or the response at infinite concentration, Max is the top or the response at 0 concentration, $\log \mathrm{EC}_{50}$ is the concentration when the response is halfway between Min and Max and $n_{H}$ is the Hill Slope. The limit of detection (LoD) was calculated using three times the standard deviation (SD) of raw binding signals of the highest point of the calibration curve, corresponding to the lower toxin concentration, 
and interpolating this value in the calibration curve. The Student's t-test for unpaired data was used for statistical analysis, except for multiple comparisons, which were performed using ANOVA $(\mathrm{p}<0.05)$.

\section{Results and Discussion}

This study presents for the first time a flow fluorimetry-based competition immunoassay to detect AZAs using a specific antibody. The assay design consist of the competition of free AZA toxins and AZA-2 immobilized on the surface of microspheres for binding to monoclonal antibody mAb 8F4. Finally, the mAb $8 F 4$ antibody bound to AZA-2microspheres is quantified using a PE-labeled anti-mouse antibody. AZA-2 was initially selected for immobilization due to its higher reported toxicity [2,30]. The use of synthetic AZA-2 for immobilization would warrant a source of toxin for assay production independent from cultures and natural toxic blooms.

The assay was optimized for maximum sensitivity by varying antibody dilutions and incubation times. In order to evaluate sensitivity, AZA-1 calibration curves were obtained for every condition. Serial dilutions of AZA- 1 at several concentrations, ranging from 0.1 to $100 \mathrm{nM}$ or 0.01 to $100 \mathrm{nM}$, depending on expected sensitivity, were prepared in buffer (PBS-BT/10\% MeOH) and assayed with the microsphere-based detection method. At first, 1:2000 and 1:5000 dilutions of the $\mathrm{mAb} 8 \mathrm{~F} 4$ stock $(2.8 \mathrm{Fg} / \mathrm{mL})$ were tested with short incubation times (30 min for $\mathrm{Ab}+$ sample incubation, and $30 \mathrm{~min}$ for $\mathrm{Ab}+$ sample + microsphere incubation). These conditions provided calibration curves with $\mathrm{IC}_{50}$ values for AZA-1 of $7.4 \pm 1.3 \mathrm{nM}$ and $3.6 \pm 0.1 \mathrm{nM}$, for 1:2000 and 1:5000 dilutions, respectively (Fig. 2, Table 1). In order to increase the sensitivity of the method, a 1:50000 dilution of the $\mathrm{mAb} 8 \mathrm{~F} 4$ stock was also tested in combination with overnight incubation. Therefore the anti-AZA antibody was added to the calibration solution or sample for $30 \mathrm{~min}$, and then this mixture was incubated with AZA-2-microspheres overnight at $4{ }^{\circ} \mathrm{C}$ with constant shaking. These conditions provided calibration curves with an average $\mathrm{IC}_{50}$ value of $1.4 \pm 0.2 \mathrm{nM}$ (Table 1). The overnight assay also showed a wider dynamic range (Fig. 2) and a lower LoD than shorter protocols (Table 1). Moreover, this inhibition immunoassay has a high sensitivity compared to the sensitivity of previously published immunoassays for AZAs or AZA fragments [28,31].

The cross-reactivity of this AZA-detection method was also studied by comparing $\mathrm{IC}_{50}$ values of the calibration curves obtained for AZA-1, AZA-2 and AZA-3 within the same assay. Dilutions of $0.01,0.1,1,3,10,30$ and $100 \mathrm{nM}$ of the three toxins were prepared in buffer and assayed using the overnight protocol. The $\mathrm{IC}_{50}$ values obtained in these matched experiments were $1.7 \pm 0.4,4.2 \pm 0.5$ and $1.4 \pm 0.5 \mathrm{nM}$ for AZA-1, AZA-2 and AZA-3, respectively (mean $\pm \mathrm{SEM} ; \mathrm{n}=3$ ) (Figs. $3 \mathrm{~A}$ and $3 \mathrm{~B}$ ). The $\%$ cross-reactivity $(\% \mathrm{CR}$ ) was calculated as follows (AZA-1 was considered the reference toxin with $100 \%$ crossreactivity): $\% \mathrm{CR}=\left(\mathrm{IC}_{50}\right.$ of AZA-1 $/ \mathrm{IC}_{50}$ of AZA $) \times 100$. These results demonstrate that the microsphere-based immunoassay is capable of detecting AZA-1, AZA-2 and AZA-3. The assay seems to be more sensitive for AZA-1 and AZA-3 and less efficient for AZA-2 (Figs. 3A and 3B). The cross-reactivity of this immunoassay did not show a good correlation with the reported relative toxicity of these molecules $\left(\mathrm{LD}_{50}\right.$ values of $200 \mathrm{Fg} / \mathrm{kg}$, $110 \mathrm{Fg} / \mathrm{kg}$ and $140 \mathrm{Fg} / \mathrm{kg}$, for AZA-1, AZA-2 and AZA-3, respectively, intraperitoneal, mouse). $[2,30]$. However, the studies of AZA-1, 2 and 3 toxicity were performed before certified standards of these toxins where produced, and therefore the correlation of assay cross-reactivity with relative toxicity should be reevaluated when more toxicity data are available. 
The performance of the microsphere-based assay with shellfish extracts was evaluated using two extraction solvents and different shellfish matrixes. Mussel, clam, cockle and scallop extracts were prepared using a simple extraction with $\mathrm{MeOH} / \mathrm{NaOAc}$, and analyzed in duplicate following the overnight assay protocol. The extraction procedure was also carried out using methanol instead of $\mathrm{MeOH} / \mathrm{NaOAc}$, and mussels as shellfish extracts. Maximum and minimum binding signals in buffer and in shellfish extracts were compared in order to analyze the matrix effect; and no statistically significant differences were observed between the data obtained in buffer and shellfish extracts in any condition (Table 2).

Moreover, the matrix effect on the AZA-detection method was evaluated by comparing calibration curves of AZA- 1 in buffer and in mussel extract using the $\mathrm{MeOH} / \mathrm{NaOAc}$ extraction procedure. Serial dilutions of AZA-1 at concentrations of $0.01,0.1,1,3,10,30$ and $100 \mathrm{nM}$ were prepared in buffer or extract, and assayed following the overnight microsphere-based inhibition assay. Both calibration curves were very similar (Fig. 4A). The dynamic range $\left(\mathrm{IC}_{20}-\mathrm{IC}_{80}\right)$, estimated $\mathrm{LoD}$ and $\mathrm{IC}_{50}$ values for AZA-1 obtained in shellfish extract were very close to the values obtained in buffer (Fig. 4B). The lack of matrix interference suggests that the quantification of the AZA content in natural samples could be performed using a calibration curve in buffer.

Considering sample dilution during the $\mathrm{MeOH} / \mathrm{NaOAc}$ extraction protocol, the dynamic range of the assay in extract and the LoD (Fig. 4B), the microsphere-based immunoassay is able to detect AZA-1 in the range of $15-280 \mu \mathrm{g} / \mathrm{kg}$ in shellfish meat. The EU has set a regulatory limit for AZAs of $160 \mu \mathrm{g} / \mathrm{kg}$ [19], which is within the range of our assay.

The recovery of AZA-1 with this sample extraction protocol was also evaluated using methanol or $\mathrm{MeOH} / \mathrm{NaOAc}$ as extraction solutions. For this purpose, an aliquot $(1 \mathrm{~g})$ of blank mussel homogenate was spiked with $84 \mathrm{ng}$ of AZA-1. The spiked blank materials were extracted following the procedure described above and analyzed with the overnight microsphere-based immunoassay. The toxin content was quantified using calibration curves in $\mathrm{MeOH} / \mathrm{NaOAc}$ or methanol extract depending on the solvent used for sample extraction, and the recovery rate was calculated as follows: $\%$ Recovery $=$ (measured content / fortification level) $\times 100$. The amount of AZA-1 detected by the microsphere-based assay in $1 \mathrm{~g}$ of mussel was $72.7 \mathrm{ng}$ in the $\mathrm{MeOH} / \mathrm{NaOAc}$ extract and $63.7 \mathrm{ng}$ in the methanol extract, resulting in recovery efficiencies of $86.5 \%$ and $75.8 \%$, respectively. These results indicate that both methanol and $\mathrm{MeOH} / \mathrm{NaOAc}$ extracts are adequate in terms of recovery and matrix effects for shellfish sample screening. The extraction with $\mathrm{MeOH}$ is used for AZA detection by LC-MS/MS [29], however, for a multiplexed assay using Luminex technology with the capability of multidetection of hydrophilic and lipophilic toxins, we have been testing a combination of $\mathrm{MeOH}$ and acetate buffer to favor extraction of some hydrophilic toxins. The inclusion of acetate buffer in the extraction solution seems to improve AZA-1 recovery; and, additionally, it will facilitate inclusion of this single assay in a multiplexed marine toxin assay [32]. In summary, this paper reports, for the first time, a new sensitive screening assay to detect AZAs in the range of the European regulatory limit using a microsphere/flow fluorimetry-based immunoassay. This detection method could be included in the future in a multiplexed assay to allow the simultaneous detection of several groups of toxins in the same sample.

\section{Acknowledgments}

This work was funded with the following FEDER co-funded-grants: From Ministerio de Ciencia y Tecnología, Spain: SAF2009-12581 (subprograma NEF), AGL2009 13581-CO2-01, TRA2009-0189, AGL2010-17875. From Xunta de Galicia, Spain: GRC 2010/10, and PGDIT 07MMA006261PR, PGIDIT (INCITE) 09MMA003261PR, PGDIT (INCITE) 09261080PR, 2009/XA044, and 10PXIB261254 PR. From EU VIIth Frame Program: 211326 CP (CONffIDENCE), 265896 BAMMBO, 265409 FAQUA, and 262649 BEADS, 312184 PharmaSea. From the 
Atlantic Area Programme (Interreg IVB Trans-national): 2009-1/117 Pharmatlantic. From the National Institutes of Health (USA) (Grant ESØ13314, to KCN).

\section{References}

1. McMahon T, Silke J. Winter toxicity of unknown aetiology in mussels. Harmful Algae News. 1996; $14: 2$.

2. Satake M, Ofuji K, Naoki H, James KJ, Furey A, McMahon T, Silke J, Yasumoto T. Azaspiracid, a new marine toxin having unique spiro ring assemblies, isolated from Irish mussels, Mytilus edulis. J Am Chem Soc. 1998; 120:9967-9968.

3. Tillmann U, Elbrachter M, Krock B, John U, Cembella A. Azadinium spinosum gen. et sp. nov. (Dinophyceae) identified as a primary producer of azaspiracid toxins. Eur J Phycol. 2009; 44:63-79.

4. Nicolaou KC, Chen DYK, Li Y, Qian W, Ling T, Vyskocil S, Koftis TV, Govindasamy M, Uesaka N. Total synthesis of the proposed azaspiracid-1 structure, Part 2: coupling of the C1-C20, C21C27, and C28-C40 fragments and completion of the synthesis. Angew Chem Int Ed Engl. 2003; 42:3649-3653. [PubMed: 12916037]

5. Nicolaou KC, Chen DYK, Li Y, Uesaka N, Petrovic G, Koftis TV, Bernal F, Frederick MO, Govindasamy M, Ling T, Pihko PM, Tang W, Vyskocil S. Total synthesis and structural elucidation of azaspiracid-1. Synthesis-based analysis of originally proposed structures and indication of their non-identity to the natural product. J Am Chem Soc. 2006; 128:2258-2267. [PubMed: 16478179]

6. Nicolaou KC, Koftis TV, Vyskocil S, Petrovic G, Ling T, Yamada YMA, Tang W, Frederick MO. Structural revision and total synthesis of azaspiracid-1, Part 2: definition of the ABCD domain and total synthesis. Angew Chem Int Ed. 2004; 43:4318-4324.

7. Nicolaou KC, Koftis TV, Vyskocil S, Petrovic G, Tang W, Frederick MO, Chen DYK, Li Y, Ling T, Yamada YMA. Total synthesis and structural elucidation of azaspiracid-1. Final assignment and total synthesis of the correct structure of azaspiracid-1. J Am Chem Soc. 2006; 128:2859-2872. [PubMed: 16506764]

8. Nicolaou KC, Li Y, Uesaka N, Koftis TV, Vyskocil S, Ling T, Govindasamy M, Bernal F, Chen DYK. Total synthesis of the proposed azaspiracid-1 structure, Part 1: Construction of the enantiomerically pure C1-C20, C21-C27, and C28-C40 fragments. Angew Chem Int Ed Engl. 2003; 42:3643-3648. [PubMed: 12916036]

9. Nicolaou KC, Pihko PM, Bernal F, Frederick MO, Qian W, Uesaka N, Diedrichs N, Hinrichs J, Koftis TV, Loizidou E, Petrovic G, Rodriquez M, Sarlah D, Zou N. Total synthesis and structural elucidation of azaspiracid-1. Construction of key building blocks for originally proposed structure. J Am Chem Soc. 2006; 128:2244-2257. [PubMed: 16478178]

10. Nicolaou KC, Vyskocil S, Koftis TV, Yamada YMA, Ling T, Chen DYK, Tang W, Petrovic G, Frederick MO, Li Y, Satake M. Structural revision and total synthesis of azaspiracid-1, Part 1: intelligence gathering and tentative proposal. Angew Chem Int Ed Engl. 2004; 43:4312-4318. [PubMed: 15368380]

11. Rehmann N, Hess P, Quilliam MA. Discovery of new analogs of the marine biotoxin azaspiracid in blue mussels (Mytilus edulis) by ultra-performance liquid chromatography/tandem mass spectrometry. Rapid Commun Mass Spectrom. 2008; 22:549-558. [PubMed: 18228242]

12. Álvarez G, Uribe E, Avalos P, Marino C, Blanco J. First identification of azaspiracid and spirolides in Mesodesma donacium and Mulinia edulis from Northern Chile. Toxicon. 2010; 55:638-641. [PubMed: 19631679]

13. James KJ, Furey A, Lehane M, Ramstad H, Aune T, Hovgaard P, Morris S, Higman W, Satake M, Yasumoto T. First evidence of an extensive northern European distribution of azaspiracid poisoning (AZP) toxins in shellfish. Toxicon. 2002; 40:909-915. [PubMed: 12076644]

14. Klontz KC, Abraham A, Plakas SM, Dickey RW. Mussel-associated azaspiracid intoxication in the United States. Ann Intern Med. 2009; 150:361. [PubMed: 19258569]

15. Magdalena AB, Lehane M, Krys S, Fernandez ML, Furey A, James KJ. The first identification of azaspiracids in shellfish from France and Spain. Toxicon. 2003; 42:105-108. [PubMed: 12893067]

16. Taleb H, Vale P, Amanhir R, Benhadouch A, Sagou R, Chafik A. First detection of azaspiracid in mussels in north west Africa. J Shellfish Res. 2006; 25:1067-1070. 
17. Ueoka R, Ito A, Izumikawa M, Maeda S, Takagi M, Shin-ya K, Yoshida M, Van Soest RWM, Matsunaga S. Isolation of azaspiracid-2 from a marine sponge Echinoclathria sp. as a potent cytotoxin. Toxicon. 2009; 53:680-684. [PubMed: 19233223]

18. EFSA. Marine biotoxins in shellfish-Azaspiracid group:scientific opinion of the panel of contaminants in the food chain. EFSA J. 2008; 723:1-52.

19. EC. Regulation (EC) No 853/2004 of the European Parliament and of the Council of April 29, 2004 laying down specific hygiene rules for food of animal origin, L139, 55. Off J Eur Communities. 2004

20. Ito E, Satake M, Ofuji K, Kurita N, McMahon T, James KJ, Yasumoto T. Multiple organ damage caused by a new toxin azaspiracid, isolated from mussels produced in Ireland. Toxicon. 2000; 38:917-930. [PubMed: 10728830]

21. Twiner MJ, Rehmann N, Hess P, Doucette GJ. Azaspiracid shellfish poisoning: a review on the chemistry, ecology, and toxicology with an emphasis on human health impacts. Mar Drugs. 2008; 6:39-72. [PubMed: 18728760]

22. EU. Commission Regulation (EU) No 15/2011 of 10 January 2011 amending Regulation (EC) No 2074/2005 as regards recognised testing methods for detecting marine biotoxins in live bivalve molluscs. Off J Eur Union L6, 11/01/2011. 2011

23. Otero P, Alfonso A, Alfonso C, Rodríguez P, Vieytes MR, Botana LM. Effect of uncontrolled factors in a validated liquid chromatography-tandem mass spectrometry method question its use as a reference method for marine toxins: major causes for concern. Anal Chem. 2011; 83:5903-5911. [PubMed: 21651235]

24. Peters J, Bienenmann-Ploum M, De Rijk T, Haasnoot W. Development of a multiplex flow cytometric microsphere immunoassay for mycotoxins and evaluation of its application in feed. Mycotoxin Res. 2011; 27:63-72. [PubMed: 21836765]

25. Meimaridou A, Kalachova K, Shelver WL, Franek M, Pulkrabova J, Haasnoot W, Nielen MW. Multiplex screening of persistent organic pollutants in fish using spectrally encoded microspheres. Anal Chem. 2011; 83:8696-8702. [PubMed: 21961972]

26. Nicolaou KC, Frederick MO, Loizidou EZ, Petrovic G, Cole KP, Koftis TV, Yamada YM. Second-generation total synthesis of azaspiracids-1, -2, and -3. Chem Asian J. 2006; 1:245-263. [PubMed: 17441061]

27. Nicolaou KC, Frederick MO, Petrovic G, Cole KP, Loizidou EZ. Total synthesis and confirmation of the revised structures of azaspiracid-2 and azaspiracid-3. Angew Chem Int Ed Engl. 2006; 45:2609-2615. [PubMed: 16548033]

28. Frederick MO, De Lamo Marin S, Janda KD, Nicolaou KC, Dickerson TJ. Monoclonal antibodies with orthogonal azaspiracid epitopes. Chembiochem. 2009; 10:1625-1629. [PubMed: 19492388]

29. EU-Harmonised Standard Operating Procedure for determination of Lipophilic marine biotoxins in molluscs by LC-MS/MS. 2011. http://www.aesan.msssi.gob.es/CRLMB/web/ procedimientos_crlmb/crlmb_standard_operating_procedures.shtml

30. Ofuji K, Satake M, McMahon T, Silke J, James KJ, Naoki H, Oshima Y, Yasumoto T. Two analogs of azaspiracid isolated from mussels, Mytilus edulis, involved in human intoxication in Ireland. Nat Toxins. 1999; 7:99-102. [PubMed: 10647511]

31. Forsyth CJ, Xu J, Nguyen ST, Samdal IA, Briggs LR, Rundberget T, Sandvik M, Miles CO. Antibodies with broad specificity to azaspiracids by use of synthetic haptens. J Am Chem Soc. 2006; 128:15114-15116. [PubMed: 17117862]

32. Fraga M, Vilariño N, Louzao MC, Rodríguez P, Campbell K, Elliott CT, Botana LM. Multidetection of paralytic, diarrheic, and amnesic shellfish toxins by an inhibition immunoassay using a microsphere-flow cytometry system. Anal Chem. 2013:7794-7802. [PubMed: 23859142] 


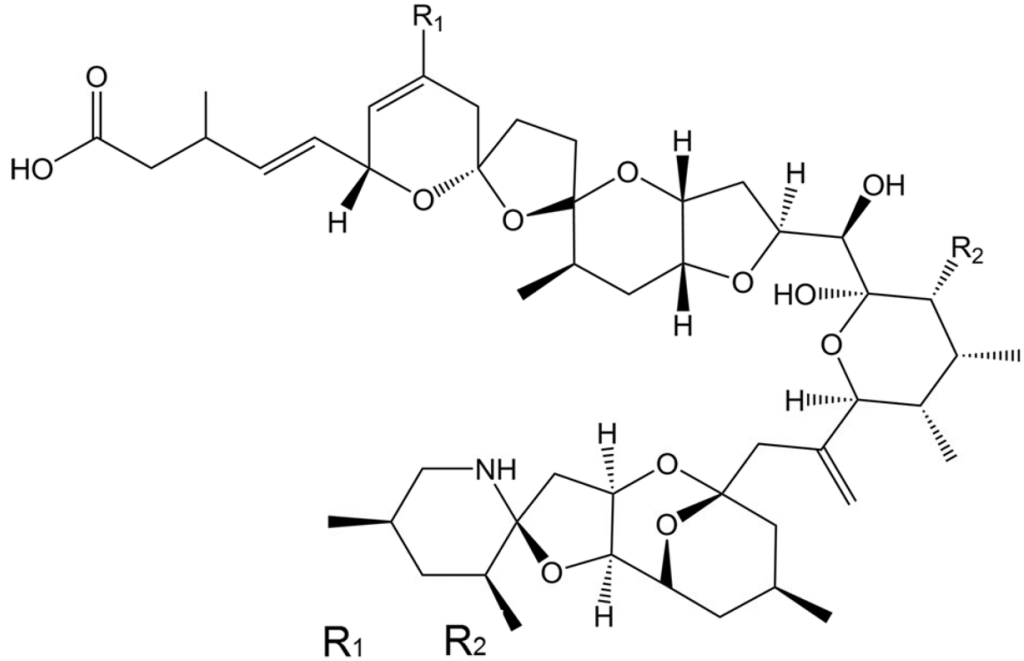

\section{Azaspiracid-1 $\mathrm{H} \quad \mathrm{CH}_{3}$ Azaspiracid-2 $\mathrm{CH}_{3} \quad \mathrm{CH}_{3}$ Azaspiracid-3 $\mathrm{H} \quad \mathrm{H}$}

Fig. 1.

Chemical structure of AZA-1, AZA-2 and AZA-3. 


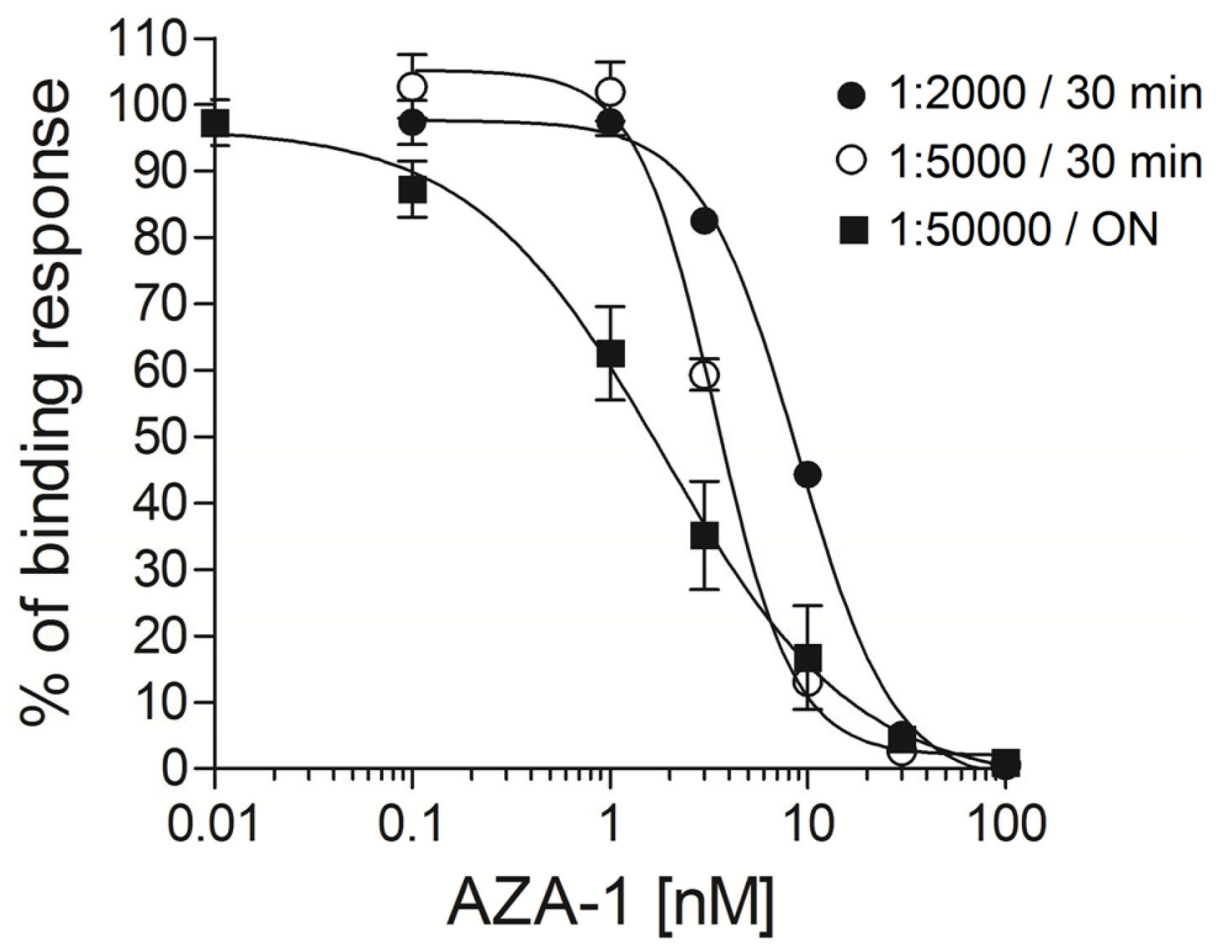

Fig. 2.

Calibration curves of AZA-1 in buffer using the microsphere-based inhibition assay with several assay conditions. Calibration curves were obtained using the inhibition assay with mAb 8F4 dilutions of 1:2000 and 1:5000 combined with 30 min incubations, and 1:50000 combined with an overnight incubation with AZA-2-coated microspheres. Data are expressed as percentage of maximum mAb $8 F 4$ binding. The three calibration curves belong to non-matched experiments (mean $\pm \mathrm{SEM} ; \mathrm{n}=4$ for $1: 2000$ dilution, $\mathrm{n}=3$ for $1: 5000$ dilution and $\mathrm{n}=7$ for 1:50000 dilution). 


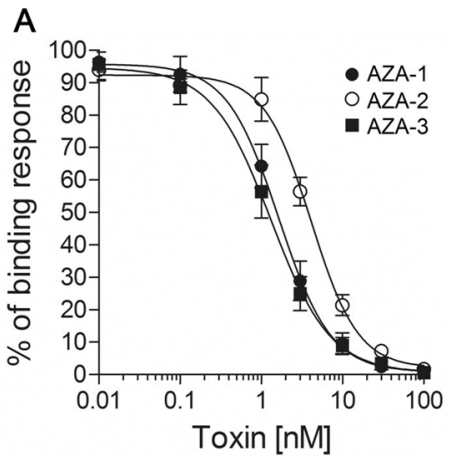

B
\begin{tabular}{|c|c|c|c|}
\hline & $A Z A-1$ & $A Z A-2$ & $A Z A-3$ \\
\hline IC $50(\mathrm{nM})$ & $1.7 \pm 0.4$ & $4.2 \pm 0.5$ & $1.4 \pm 0.5$ \\
IC $50(\mathrm{ng} / \mathrm{mL})$ & $1.4 \pm 0.3$ & $3.6 \pm 0.5$ & $1.1 \pm 0.4$ \\
\hline $\mathrm{IC}_{20}(\mathrm{nM})$ & $0.6 \pm 0.1$ & $1.6 \pm 0.2$ & $0.5 \pm 0.2$ \\
$I_{20}(\mathrm{ng} / \mathrm{mL})$ & $0.5 \pm 0.1$ & $1.4 \pm 0.2$ & $0.4 \pm 0.2$ \\
\hline IC $80(\mathrm{nM})$ & $4.7 \pm 1.2$ & $11.0 \pm 1.1$ & $4.1 \pm 0.8$ \\
IC $80(\mathrm{ng} / \mathrm{mL})$ & $3.9 \pm 1.0$ & $9.4 \pm 0.9$ & $3.4 \pm 0.7$ \\
\hline LoD $(\mathrm{nM})$ & $0.8 \pm 0.3$ & $2.1 \pm 0.2$ & $1.3 \pm 1.1$ \\
LoD $(\mathrm{ng} / \mathrm{mL})$ & $0.6 \pm 0.2$ & $1.8 \pm 0.2$ & $1.1 \pm 0.9$ \\
\hline$\% \% \mathrm{CR}$ & 100 & $42 \pm 8$ & $138 \pm 17$ \\
\hline
\end{tabular}

Fig. 3.

Cross-reactivity profile of AZA-1, AZA-2 and AZA-3 using the overnight microspherebased inhibition assay. (A) Calibration curves of AZA-1, AZA-2 and AZA-3. Calibration solutions were prepared at concentrations ranging from 0.01 to $100 \mathrm{nM}$ in buffer for the three toxins and assayed using the inhibition assay. The data are expressed as a percentage of maximum mAb $8 \mathrm{~F} 4$ binding response. The calibration curves were obtained with a fourparameter fit. (B) $\mathrm{IC}_{50}$, dynamic range, LoD and \% cross-reactivity (\% CR) values for AZA-1, AZA-2 and AZA-3. Data obtained from the curves in (A) (mean \pm SEM; $n=3$ ). 
A

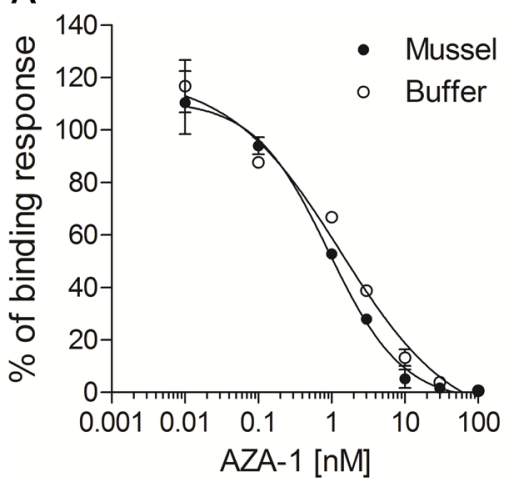

B

\begin{tabular}{|c|c|c|}
\hline & Mussel & Buffer \\
\hline$I_{50}(n M)$ & $0.88 \pm 0.21$ & $1.07 \pm 0.27$ \\
\hline $1 C_{50}(n g / m L)$ & $0.74 \pm 0.18$ & $0.90 \pm 0.23$ \\
\hline $\mathrm{IC}_{20}(\mathrm{nM})$ & $0.19 \pm 0.11$ & $0.14 \pm 0.08$ \\
\hline $1 C_{20}(n g / m L)$ & $0.16 \pm 0.09$ & $0.11 \pm 0.07$ \\
\hline $\mathrm{IC}_{80}(\mathrm{nM})$ & $3.90 \pm 0.54$ & $7.43 \pm 0.97$ \\
\hline $1 C_{80}(\mathrm{ng} / \mathrm{mL})$ & $3.29 \pm 0.46$ & $6.25 \pm 0.81$ \\
\hline LoD (nM) & $0.36 \pm 0.04$ & $0.43 \pm 0.24$ \\
\hline$L o D(n g / m L)$ & $0.30 \pm 0.04$ & $0.36 \pm 0.21$ \\
\hline
\end{tabular}

Fig. 4.

Effect of mussel matrix on the detection of AZA-1 using the microsphere-based Luminex system. (A) Calibration curves of AZA-1 in buffer and shellfish extract using the overnight microsphere-based immunoassay and $\mathrm{MeOH} / \mathrm{NaOAc}$ as extraction solvent. AZA-1 standard was diluted at concentrations ranging from $0.01-100 \mathrm{nM}$ in buffer and mussel extract. The data are expressed as a percentage of maximum mAb $8 \mathrm{~F} 4$ binding response. The calibration curves were obtained with a four-parameter fit (mean $\pm \mathrm{SEM}$ of two replicates). (B) $\mathrm{IC}_{50}$, dynamic range $\left(\mathrm{IC}_{20}-\mathrm{IC}_{80}\right)$ and $\mathrm{LoD}$ values obtained from the curves in $(\mathrm{A})$. 


\section{Table 1}

$\mathrm{IC}_{50}$, dynamic range $\left(\mathrm{IC}_{20}-\mathrm{IC}_{80}\right)$, limit of detection ( $\left.\mathrm{LoD}\right)$ and maximum and minimum binding signal of the microsphere-based assay for AZA-1 in buffer with several assay conditions. $\mathrm{The}^{\mathrm{IC}} \mathrm{C}_{50}, \mathrm{IC}_{20}, \mathrm{IC}_{80}, \mathrm{LoD}$ and binding signals values were obtained from the experiments that generated Fig. 2 using a four-parameter fit equation (mean $\pm \mathrm{SEM}, \mathrm{n}=4$ for $1: 2000 \mathrm{mAb} 8 \mathrm{~F} 4$ dilution, $\mathrm{n}=3$ for $1: 5000 \mathrm{mAb} 8 \mathrm{~F} 4$ dilution and $\mathrm{n}=7$ for 1:50000 mAb 8F4 dilution).

\begin{tabular}{|c|c|c|c|}
\hline Incubation time & \multicolumn{2}{|c|}{30 min } & Overnight \\
\hline mAb 8F4 dilution & $\mathbf{1 : 2 0 0 0}$ & $\mathbf{1 : 5 0 0 0}$ & $\mathbf{1 : 5 0 0 0 0}$ \\
\hline $\mathrm{IC}_{50}(\mathrm{nM})$ & $7.4 \pm 1.3$ & $3.6 \pm 0.1$ & $1.4 \pm 0.2$ \\
$I C_{50}(\mathrm{ng} / \mathrm{mL})$ & $6.2 \pm 1.1$ & $3.0 \pm 0.1$ & $1.2 \pm 0.2$ \\
\hline $\mathrm{IC}_{20}(\mathrm{nM})$ & $4.3 \pm 0.4$ & $1.9 \pm 0.0$ & $0.4 \pm 0.1$ \\
$I C_{20}(\mathrm{ng} / \mathrm{mL})$ & $3.6 \pm 0.3$ & $0.7 \pm 0.0$ & $0.3 \pm 0.1$ \\
\hline $\mathrm{IC}_{80}(\mathrm{nM})$ & $18.8 \pm 0.7$ & $6.8 \pm 0.0$ & $5.6 \pm 1.2$ \\
$I C_{80}(\mathrm{ng} / \mathrm{mL})$ & $15.8 \pm 0.6$ & $5.7 \pm 0.0$ & $4.7 \pm 1.0$ \\
\hline LoD $(\mathrm{nM})$ & $2.6 \pm 0.4$ & $1.5 \pm 0.1$ & $1.0 \pm 0.6$ \\
$L o D(n g / m L)$ & $2.2 \pm 0.3$ & $1.3 \pm 0.1$ & $0.8 \pm 0.5$ \\
\hline Maximum Binding Signal $(\mathrm{RU})$ & $2109 \pm 180$ & $1052 \pm 78$ & $617 \pm 159$ \\
\hline Minimum Binding Signal $(\mathrm{RU})$ & $2.6 \pm 0.2$ & $2.3 \pm 0.2$ & $3.2 \pm 0.1$ \\
\hline
\end{tabular}


Table 2

Matrix effect of $\mathrm{MeOH} / \mathrm{NaOAc}$ or methanol shellfish extracts on maximum and minimum binding signals using the overnight microsphere-based inhibition assay (mean $\pm S E M ; n=3$ ).

\begin{tabular}{|c|c|c|}
\hline \multicolumn{3}{|c|}{$\mathrm{MeoH} / \mathrm{NaOAc}$} \\
\hline & Maximum Binding Signal (RU) & Minimum Binding Signal (RU) \\
\hline Mussel & $1519 \pm 292$ & $1.8 \pm 0.2$ \\
\hline Scallop & $1613 \pm 193$ & $1.7 \pm 0.2$ \\
\hline Clam & $1637 \pm 139$ & $2.4 \pm 0.1$ \\
\hline Cockle & $1680 \pm 207$ & $2.0 \pm 0.3$ \\
\hline Buffer & $1644 \pm 398$ & $2.0 \pm 0.0$ \\
\hline \multicolumn{3}{|c|}{ Methanol } \\
\hline & Maximum Binding Signal (RU) & Minimum Binding Signal (RU) \\
\hline Mussel & $971 \pm 313$ & $3.8 \pm 1.3$ \\
\hline Buffer & $1109 \pm 409$ & $3.7 \pm 0.9$ \\
\hline
\end{tabular}

